\title{
Processes of spectralization: From Josquin's Missa "L'homme armé" Super Voces Musicales to Haas's Tria ex Uno
}

\author{
Mike Ford
}

What some scholars have called the school of spectral music emerged early in the 1970's, with composers making sound itself their object of study and their primary source of material. ${ }^{1}$ Where many earlier composers have ignored or neglected the expressive capabilities of timbre, composers of spectral music have made it the primary element in their works, using the overtone series as a point of reference. ${ }^{2}$ Robert Hasegawa maintains that "the essential characteristic of spectralism is the dissection of sounds into collections of partials or overtones as a major compositional and conceptual device. Spectral composers use the acoustical fingerprints of sounds-their spectra-as basic musical material." ${ }^{3} \mathrm{My}$ research points out an aspect of spectral music that has not been fully explored yet: the use of musical borrowing-the application of spectral techniques to existing material. In this paper, I discuss the spectral treatment of existing music in Georg Friedrich Haas's Tria ex Uno, demonstrating the distinctive spectral paradigms and techniques that Haas has used to transform the second Agnus Dei from Josquin Desprez's Missa "L'homme armé" Super Voces Musicales into Tria ex Uno. These techniques include the emphasis on timbre; a nonlinear view of musical time; the use of the harmonic spectrum, stretched and compressed versions of that spectrum, and polyspectrality, i.e. the simultaneous use of more two or more spectra; and organizing the music through processes instead of progressions. The borrowing techniques and treatment of existing music used in Tria ex Uno are found in many other quotational works by composers of spectral music, and my aim is thus to expand the discourse on musical borrowing to include spectralization.

Joshua Fineberg, "Spectral Music," Contemporary Music Review 19, No. 2 (2000): 3.

2 François Rose, "Introduction to the Pitch Organization of French Spectral Music," Perspectives of New Music 34, No. 2 (1996): 7.

3 Robert Hasegawa, "Gérard Grisey and the 'Nature' of Harmony," Music Analysis 28, No. 2-3 (2009): 349. 
Austrian composer Georg Friedrich Haas-former lecturer at Hochschule für Musik, Basel, Switzerland and currently professor of composition at Columbia University-wrote Tria ex Uno in 2001. The work is in three parts and is scored for sextet comprising flute, clarinet, piano, percussion, violin, and cello (the winds double on alto flute and bass clarinet, respectively). Haas extensively borrows material from the second Agnus Dei from Josquin Desprez's Missa “L'homme armé" Super Voces Musicales, which was published by Ottaviano Petrucci half a millennium earlier in $1502^{4}$ (Ex. 1).

Ex. 1: Agnus Dei II from Missa "L'homme armé" Super Voces Musicales ${ }^{5}$

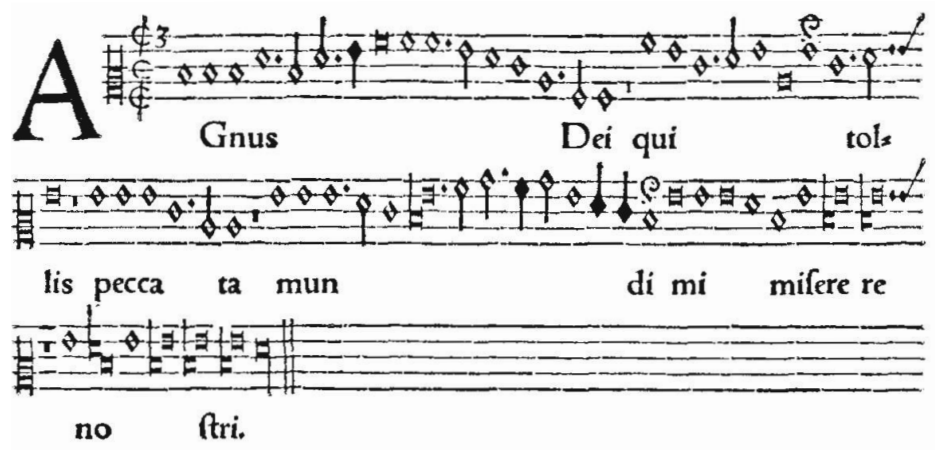

Julian Anderson argues that many composers of spectral music struggle to find ways to write melodies or counterpoint. ${ }^{6}$ By borrowing material from the Agnus Dei, Haas avoids this struggle by extracting melodic and contrapuntal fragments from a work that is explicitly contrapuntal. The Agnus Dei is a mensuration canon in three parts: the three voices simultaneously sing the same melody, but in three different mensurations. Haas presents the canon, unchanged, in Tria ex Uno I (Ex. 2).

Ex. 2: Original mensuration canon, Tria ex Uno I, mm. 1-8

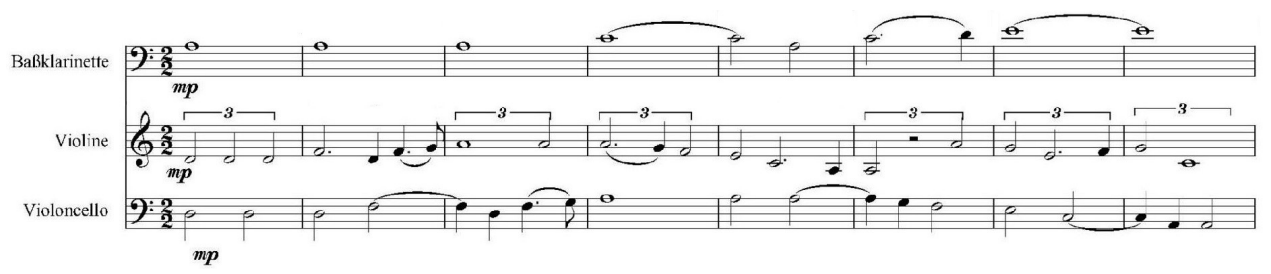

4 Patrick Macey, et al., "Josquin des Prez," in Grove Music Online. Oxford Music Online (Oxford University Press), accessed June 10, 2015, http://www.oxfordmusiconline.com.proxy.libraries.rutgers. edu/subscriber/article/grove/music/14497pg12..

5 Ex. 1 is taken from Heinrich Glarean, Dodecachordon (Basel: Heinrich Petri, 1547), 442.

6 Julian Anderson, "A Provisional History of Spectral Music," Contemporary Music Review 19, No. 2 (2000): 15-16. 


\section{Musical Borrowing}

J. Peter Burkholder has argued that three types of questions need to be addressed when examining a work that employs musical borrowing: the analytical, the historical, and the interpretive. ${ }^{7}$ Analytical questions inquire into the origin of the material and the way it has been used in the new work. While Haas makes the provenance of the material clear in the score, the answer to the second question, how it is used, or how it has been altered, is not as clear and therefore necessitates a thorough investigation, which will occupy a considerable portion of this paper.

The second of Burkholder's question types, the historical, reflects upon about the history and tradition of the specific musical practices at play in Haas's work. Joseph Straus maintains that borrowing from predecessors "seems to be almost as old as Western music itself," ${ }^{8}$ but that the twentieth century saw an unusually strong interest in this technique, partially as a result of the historical (and therefore stylistic) distance between composers and their source material. Straus notes that Webern highlights certain motives in his recomposition of the Ricercare from Bach's The Musical Offering, but maintains the original pitches and rhythms; while Schoenberg and Stravinsky add material to existing music in the then-current style. ${ }^{9}$ Richard Beaudoin and Joseph Moore distinguish between these two borrowing approaches: they label Webern's method "transcription," and Schoenberg's and Stravinsky's, "transdialection." ${ }^{10}$ Elsewhere, Beaudoin defines transdialections as "loose transcriptions that creatively reexpress the musical content of an original work in the distinct musical dialect of the [recomposer]." ${ }^{11}$ Haas applies transdialection in many of his works, including "In iij. Noct" (also 2001) and “...e finisci già..." (2012). The ways in which Haas treats the Agnus Dei in Tria ex Uno are consistent with many of his other works that employ musical borrowing.

Tria ex Uno is unusual in that it borrows from a work that makes use of musical borrowing itself (the Agnus Dei is taken from a cantus firmus mass, based on "L'homme armé"). Although "double borrowing" has precedents in literature and philosophy, its application to music is relatively novel. ${ }^{12}$ A notable twentieth-century precedent of "double borrowing" is Luciano Berio's Sinfonia, the third movement of which is modeled on the

7 J. Peter Burkholder, "The Uses of Existing Music: Musical Borrowing as a Field," Notes Second Series 50, No. 3 (1994): 864.

8 Joseph Straus, "Recompositions by Schoenberg, Stravinsky, and Webern," The Musical Quarterly 72, No. 3 (1986): 301-302.

9 Ibid., 306, 326.

10 Richard Beaudoin \& Joseph Moore, "Conceiving Musical Transdialection," The Journal of Aesthetics and Art Criticism 68, No. 2 (2010): 106.

11 Richard Beaudoin, “Musical Borrowing and Cavell's 'Way,”' Journal of Music Theory 54, No. 1 (2010): 95 .

12 Ibid., 100. 
Scherzo from Mahler's "Resurrection" Symphony, which is based in turn on Mahler's own song, "Des Antonius von Padua Fischpredigt."13

As Haas does not indicate the reasons behind his choice of existing material, answers to the interpretive questions, Burkholder's third catergory, remain speculative as it is unclear why the Agnus Dei was specifically selected and subjected to spectral treatment. Successful recomposers, according to Beaudoin and Moore, pursue "a determinate musical isomorphism," ${ }^{14}$ by taking distinct features of the original composition and presenting them in a new dialect, while retaining their expressive functions. The source material therefore has to have qualities that are susceptible to the composer's transdialection. I shall return to the interpretive questions near the end of this paper.

Haas presents an unaltered version Josquin's Agnus Dei in Tria ex Uno I to familiarize the listener with the material to be subsequently reworked. In Tria ex Uno II, by contrast, Haas presents the Agnus Dei in an alternate instrumentation, highlighting motivic relationships between parts. Tria ex Uno III paraphrases the Agnus Dei and subjects Josquin's material to a variety of spectral techniques.

\section{Tria ex Uno II}

In the second part of Tria ex Uno, the melodic lines of the Agnus Dei are fragmented and passed among the various players in the ensemble; the blocks in Ex. 3 trace the path of the Agnus Dei soprano part (cf. Ex. 2). Webern's recomposition of Bach's Ricercare uses a similar method of fragmentation and reorchestration that remains at the level of transcription. In Tria ex Uno II, each of the six players has at least one fragment of each part of the Agnus Dei. As the lines flow between the different players in the ensemble, the listener's attention is drawn to the unique timbre of each instrument. Composers of spectral music has brought timbre into focus not only by emphasizing different instrumental timbres (similar to Schoenberg's Klangfarbenmelodie), but also by calling attention to the inner workings of sounds themselves.

13 J. Peter Burkholder, "Borrowing," Grove Music Online, Oxford Music Online (Oxford University Press), accessed September 23, 2015, http://www.oxfordmusiconline.com.proxy.libraries.rutgers. edu/subscriber/article/grove/music/52918pg13. David Osmond-Smith, Playing on Words: A Guide to Berio's Sinfonia (London: Royal Musical Association: 1989), 40. It is interesting to note that Beaudoin disregards the fact that the movement from Mahler's symphony borrows material from the composer's own song; instead Beaudoin focusses on the technique of adding a multitude of sources to a fundamental source. Beaudoin, "Musical Borrowing," 98-99.

Beaudoin \& Moore, "Conceiving Musical Transdialection," 112. 
Ex. 3: Reorchestrated mensuration canon, Tria ex Uno II, mm. 1-8

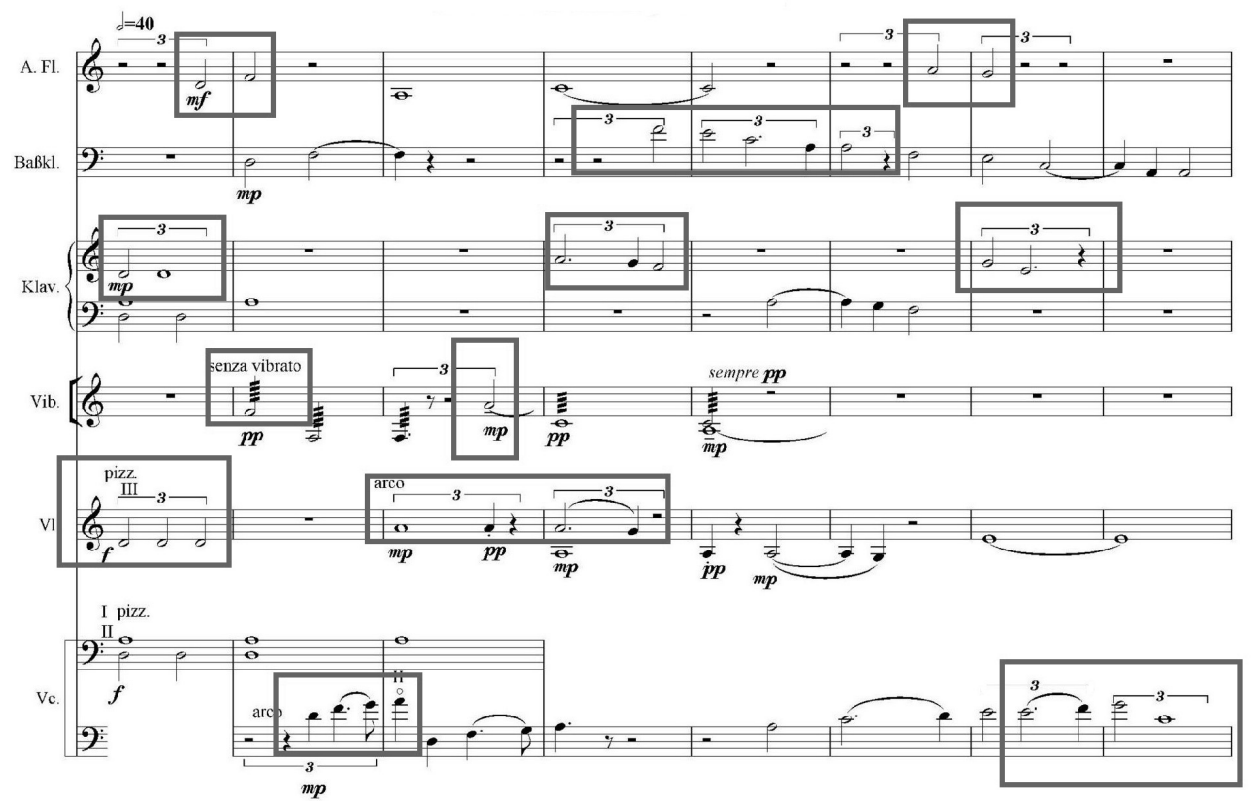

Timbres can be constructed by adding specific pitches at specific dynamic levels and at specific moments to a fundamental tone. ${ }^{15}$ This process is called "additive synthesis," and was first explicitly used in the field of electronic music. Most composers of spectral music synthesize timbres with an orchestra or ensemble; however, their goal is not to recreate the exact timbre of the synthesized tone, which is impossible because every instrument produces its own harmonic spectrum. Instead, they aim to create a hybrid sonority, in which the listener can perceive the various individual instrumental timbres as well as the collectively synthesized timbre. ${ }^{16}$ Additive synthesis allows composers to blur the line between timbre and harmony to a point of nonexistence. I discuss Haas's use of additive synthesis below.

\section{Tria ex Uno III}

The final part of Haas's work is a free composition based on the Agnus Dei. Sections in Tria ex Uno III refer to specific areas and sonorities in the movement from the mass. Haas reexpresses the existing material in his own distinct dialect, subjecting it to various

\footnotetext{
15 Joshua Fineberg, "Guide to the Basic Concepts and Techniques of Spectral Music," Contemporary Music Review 19, No. 2 (2000): 84.

16 Hasegawa, "Grisey,” 351.
} 
spectral techniques (transdialection). Tria ex Uno III is divided into two main sections, A and B. The first section (mm. 1-76) reworks the first nine measures of the Agnus Dei, and the second section (mm. 77-180) focuses on and develops only the first two measures.

Tria ex Uno III includes many techniques used by other composers of spectral music. Many of these composers view music, essentially, as sound evolving through time ${ }^{17}$ Gérard Grisey suggests that spectral compositions should explore stretched or contracted time, while Tristan Murail believes that composers of spectral music should favor logarithmic or exponential organization over linear methods. ${ }^{18}$ Examples of both Grisey's and Murail's methods can be seen in the music of Haas. Murail's nonlinear organization is evident in the proportions of subsections in Tria ex Uno III: each subsection reworks one (or in one case four) measures from the Agnus Dei, but the lengths of the subsections are nonlinear (i.e., irregular and unpredictable). Haas uses Grisey's temporal method in the reworking of Agnus Dei m. 1, stretching it from 48 seconds ${ }^{19}$ in section A to 240 seconds in section B; the reworked Agnus Dei m. 2 is 124 seconds long in section A and compressed to 44 seconds in section $\mathrm{B}$. The proportions of the various subsections in the composition are thus not organized in a linear fashion, but are governed by a different formula.

In addition to time, the idea of "process" is also central to spectral music. Composers are interested in continually transforming sound from one state to another, and use processes as the basis of form. Early spectral works often rely extensively on processes, because, according to Joshua Fineberg, composers of spectral music privilege this way of organizing music as a way to reclaim the teleological orientation that had been removed by serialism..$^{20}$ Processes usually involve gradual transformations that are perceptible rather than underlying: in the foreground rather than in the background. ${ }^{21} \mathrm{~A}$ typical process will either transform sound from a state of stability and order to one of instability and disorder (distortion), or vice versa (restoration).

Each subsection of Tria ex Uno III employs a process that transforms the sound from one state to the next. As in many other spectral works, the beginnings of subsections are harmonically stable, with clear pitches and intervals; however, gradual transformations create distortions within each subsection. ${ }^{22}$ In addition to these localized processes, larger processes take place over bigger sections of the work, following Grisey, who insists on

17 Fineberg, "Spectral Music," 3.

18 Grisey, "Did You Say Spectral," 2. Viviana Moskovich, "French Spectral Music: An Introduction," Tempo New Series 200 (1997): 22.

19 Due to spectral composers' treatment of music as sound moving through time, it is more accurate to describe proportions in temporal terms (seconds) than in notational terms (measures).

20 Fineberg, "What's in a Name," 46.

21 Fineberg, "Guide to the Basic Concepts," 108.

22 Tristan Murail, "Time and Form in Spectral Music," in Spectral World Musics ed. Robert Reigle and Paul Whitehead (Istanbul: Pan Yayıncılık, 2008), 250. Julian Anderson \& Tristan Murail, "In Harmony. Julian Anderson Introduces the Music and Ideas of Tristan Murail," The Musical Times 134, No. 1804 (1993): 321. 
the superimposition and phasing of contradictory, partial, or implied processes. ${ }^{23} \mathrm{Sec}-$ tion A, which paraphrases mm. 1-9 of the Agnus Dei, is based primarily on processes of distortion and restoration. Pitch content alien to that of a natural harmonic spectrum and the combination of two different harmonic spectra create areas of inharmonicity. Section B, paraphrasing only the first two measures, is characterized mainly by two processes: the synthesis of a harmonic spectrum and a process in which chords are gradually transformed in various ways.

\section{Section A}

In the introduction of Tria ex Uno III, Haas sets up the sonority of the opening measure from the Agnus Dei, but in a manner that suggest the synthesis of a timbre (Ex. 4). According to Hasegawa's representation tone theory, ${ }^{24}$ the opening sonority can be described as $\mathrm{D}(2: 3: 4)$, the second, third, and fourth partials of a fundamental D.

Ex. 4: Synthesized emergence of partials, mm. 1-5

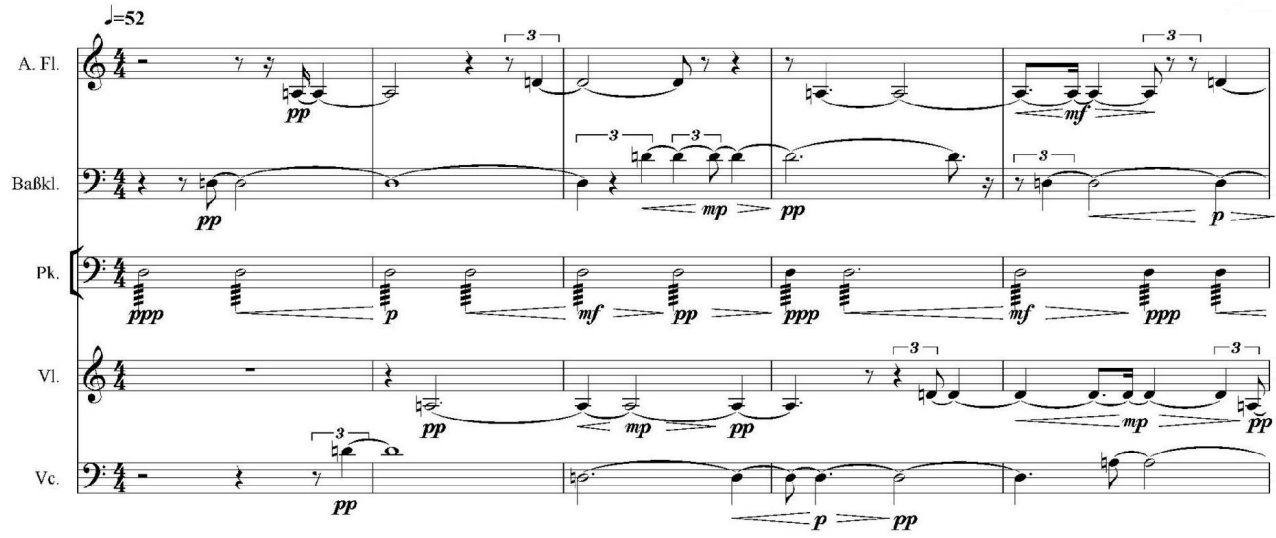

Following this, the first subsection (mm. 7-18) introduces a process of gradual distortion followed by gradual restoration. The piano holds the $\mathrm{D}(2: 3: 4)$ spectrum, while strings and bass clarinet add pitches alien to the $\mathrm{D}$ harmonic spectrum (Ex. 5). The sense of release or relaxation in spectral music relies on the listener's subconscious ability to match the various pitches to a specific fundamental tone. This is more likely to occur when the collection of notes resembles the natural harmonic spectrum..$^{25}$

23 Grisey, "Did You Say Spectral," 2-3.

24 Robert Hasegawa, "Tone Representation and Just Intervals in Contemporary Music," Contemporary Music Review 25, No. 3 (2006): 270.

25 Hasegawa, “Grisey,” 355. 
Ex. 5: Process of distortion and restoration, mm. 7-9

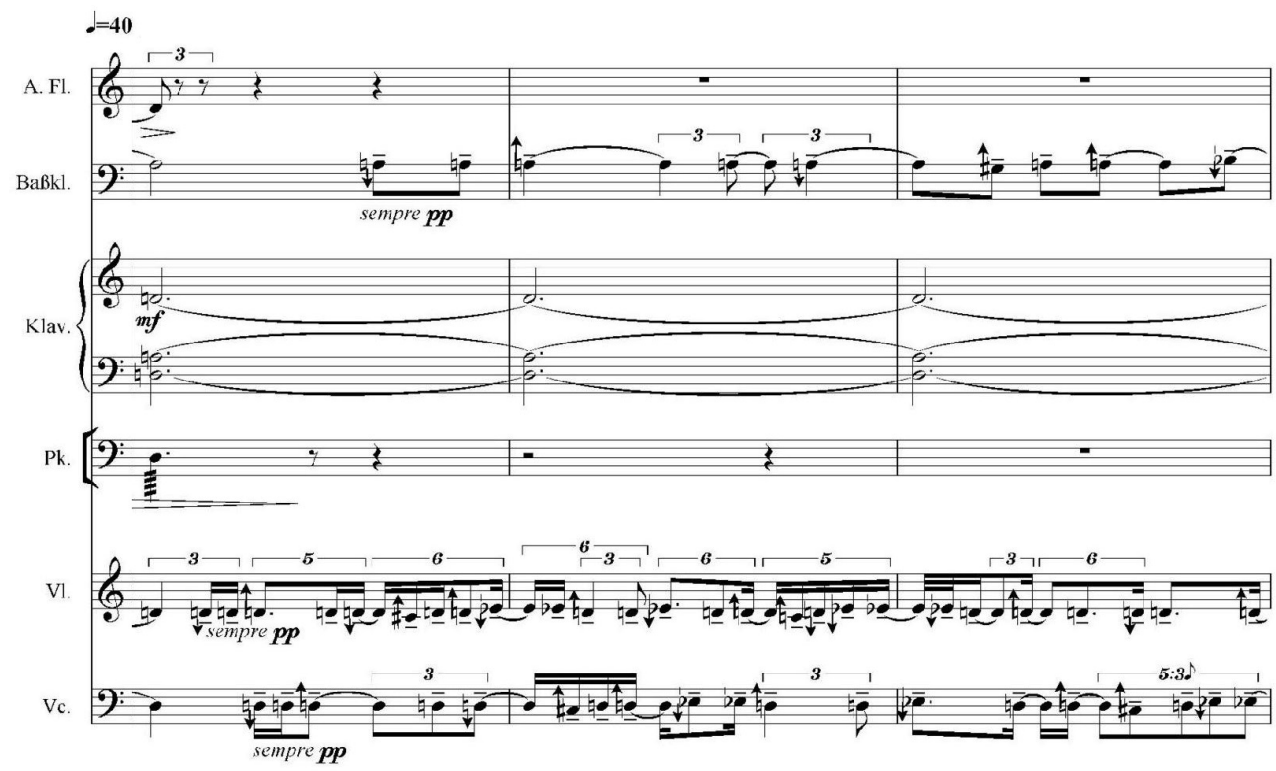

A variety of processes in subsection $2(\mathrm{~mm} .19-49)$ add the second pitch of the melody in the Agnus Dei, F, to the sonority (Ex. 6). The addition of $F$ to the D spectrum recalls the D-F dyads in the outer parts in Agnus Dei m. 2 (cf. Ex. 2). A D(2:3:4) spectrum is initially heard, to which the alto flute adds an F; the bass clarinet and alto flute then hold a D-F dyad. The violin and cello repeat a figure that gradually moves from $\mathrm{D}$ to $\mathrm{F}$ by means of a glissando; they play this figure in a canon at the unison, with a following period of two seconds.

Ex. 6: D-F processes, mm. 24-27

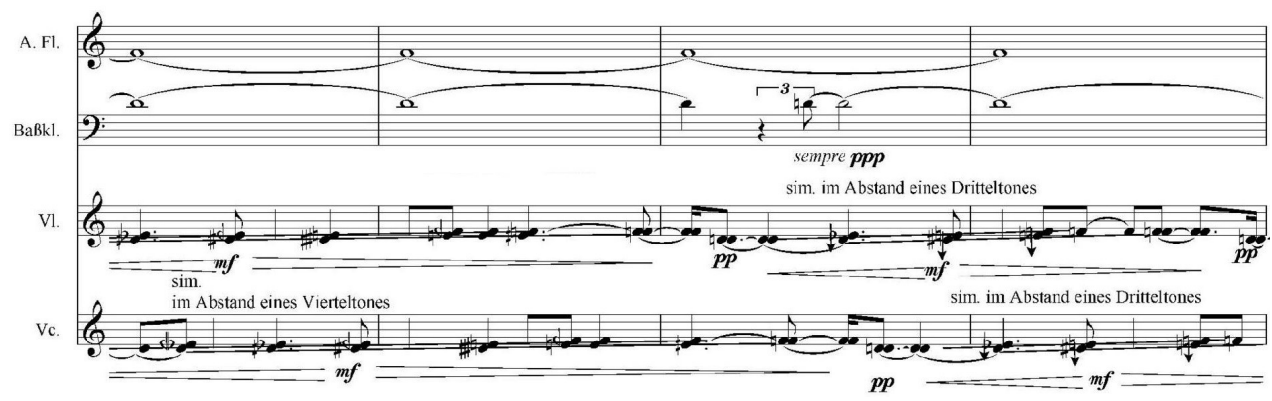

Note the large-scale process that the canon undergoes: Tria ex Uno I and II employ a mensuration canon at the fifth and octave, with all three parts starting at the same time 
(Ex. 2 and 3); subsection 1 in Tria ex Uno III introduces a following period (Ex. 5); only two parts play the canon in subsection 2, now at the unison, still with a following period, but not in different mensurations (Ex. 6).

The harmonic spectra of $\mathrm{D}$ and $\mathrm{F}$ are contrasted, creating the phenomenon known as "polyspectrality," in which two or more spectra are heard simultaneously. The bass clarinet, cello, and violin produce a $\mathrm{D}(1: 5: 7)$ spectrum; at the same time, the flute, bass clarinet, and vibraphone present an $\mathrm{F}(1: 2: 3)$ spectrum (Ex. 7).

Ex. 7: $\mathrm{D}(1: 5: 7)$ and $\mathrm{F}(1: 2: 3)$, mm. $32-36^{26}$

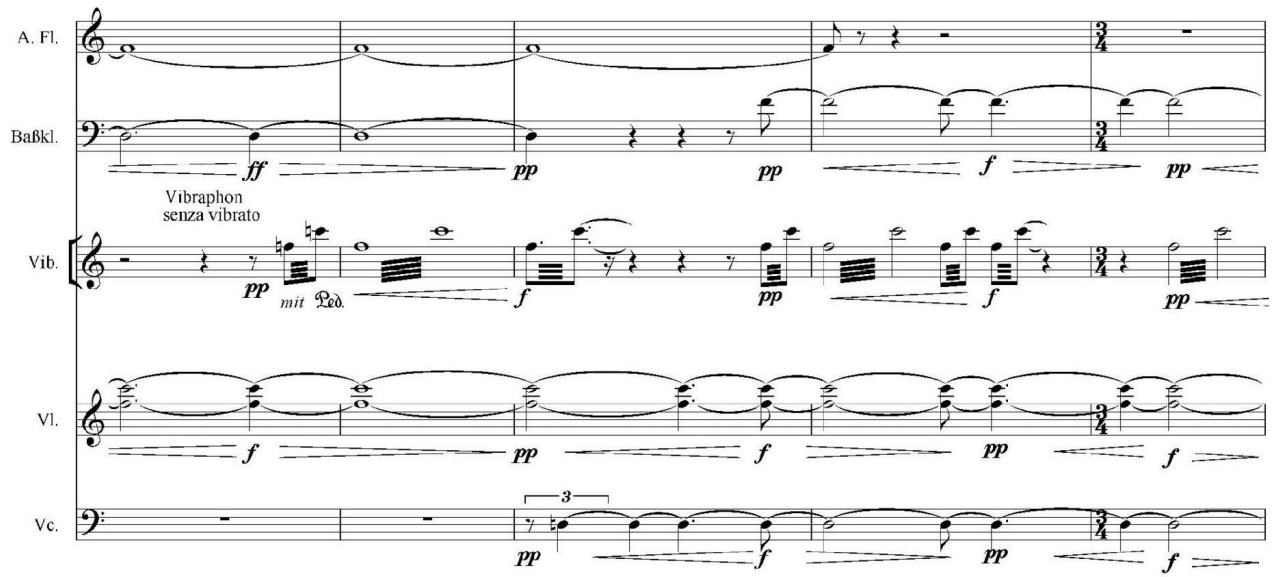

Ex. 8 shows the addition of the note A to the sonority, referring to the soprano part in Agnus Dei m. 3. The function of note is ambiguous, as it falls into both the D spectrum and the F spectrum: $\mathrm{D}(3: 8)$ and $\mathrm{F}(5: 14)$. The "poco vibrato" direction adds to this ambiguity, as the pitch differs between $\mathrm{A}$ as the third partial of $\mathrm{D}$ and $\mathrm{A}$ as the fifth partial of F: D3 has a frequency of $146.83 \mathrm{~Hz}$, creating a third partial with a frequency of $440.49 \mathrm{~Hz}$; while F2 has a frequency of $87.31 \mathrm{~Hz}$, giving its fifth partial a frequency of $436.55 \mathrm{~Hz} .^{27}$ Although all five of the active instruments sound an A, the play between two possible tone representations ensures animation and tension in a setting of low inharmonicity.

26 The violin's accidentals are held from m. 30.4ff; the notes are F-sharp and C-lowered natural, marked " $5+7$ partials of D."

27 The frequencies of the two fundamental tones are based on an equal-tempered system, using A4 $=440 \mathrm{~Hz}$. Fineberg, "Guide to the Basic Concepts," 83. 
Ex. 8: Addition of A, mm. 47-52

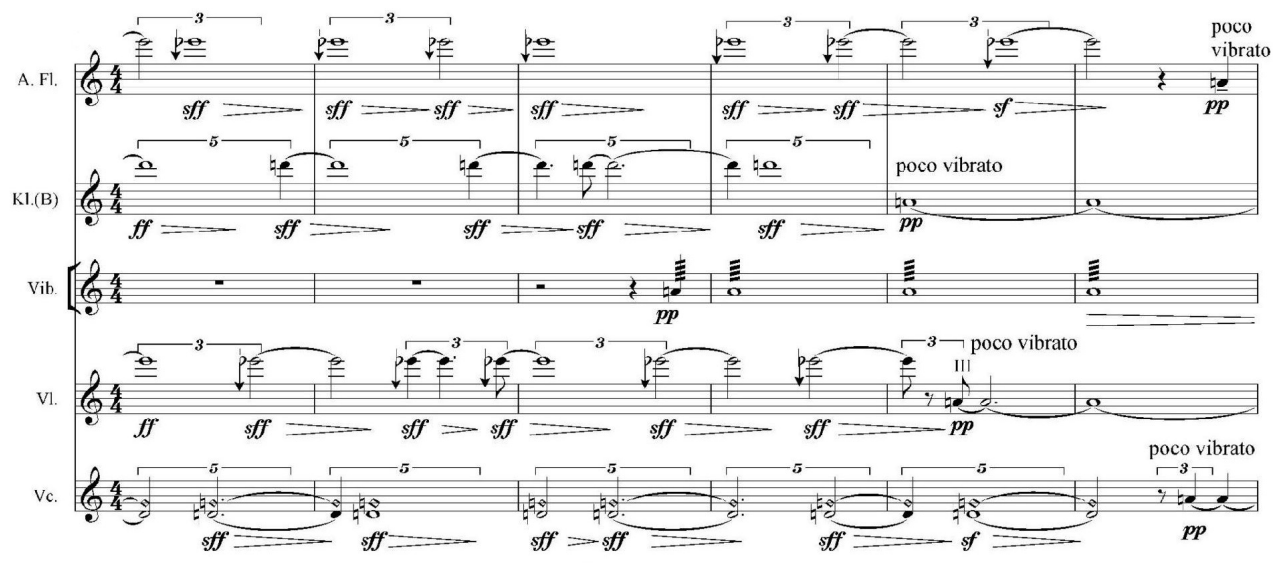

\section{Stretched and compressed spectra - Wyschnegradsky chords}

Thus far, my discussion has not touched upon the inharmonic material in the piano part. The process that transforms the state of the chords from harmonic to inharmonic takes place in subsection 1: three chords are presented in the low register of the piano, gradually distorted by being stretched out (Ex. 9).

Ex. 9: Chordal stretching, mm. 11, 15, and 17
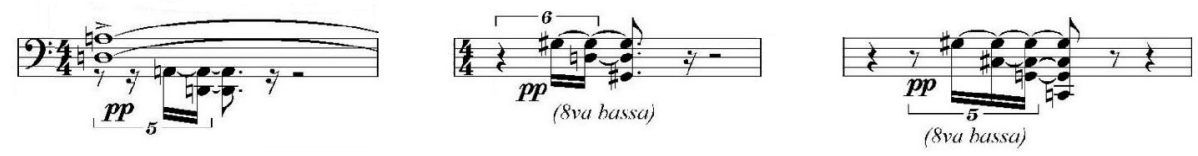

The first chord is harmonically stable and can be described as $\mathrm{D}(2: 3: 4: 6)$, derived from the opening of the Agnus Dei; the second chord is intermediary; the third chord I label "chord- $x$." It uses simple ratios from a stretched harmonic spectrum. Chord- $x$ ' is based on the same stretched spectrum as chord- $x$, with the root on the third partial, instead of on the second. Fig. 1 shows the stretched spectrum as well as chords- $x$ and $x^{\prime}$. As in tonal music, chords can be extended by adding higher octaves (harmonic or otherwise) without changing the identity of the chord.

Haas also employs the inverse: a spectrum compressed by one semitone per octave. I label chords based on this compressed spectrum as either "chord- $z$ " or "chord- $z$ " (Fig. 2). Between the chord types $x$ and $z$, there is an intermediate chord, which I label "chord-y." It is based on the natural harmonic spectrum, with the third partial and its octave equivalents lowered by one semitone (Fig. 3 and cf. central chord in Ex. 9). 
Following Haas's own terminology, Hasegawa collectively describes the sonorities that I have separately labelled as chord- $x$ and chord- $z$, as "Wyschnegradsky chords" (chords built from alternating tritones and either fourths or fifths). He maintains that Haas uses Wyschegradsky chords in various compositions, including "In iij. Noct," to emphasize the difference in tuning systems by contrasting these chords to natural harmonic spectra. ${ }^{28}$

Fig. 1: Partials 1-4, 6, 8, and 12 in natural and stretched spectra; chords- $x$ and $x^{\prime}$

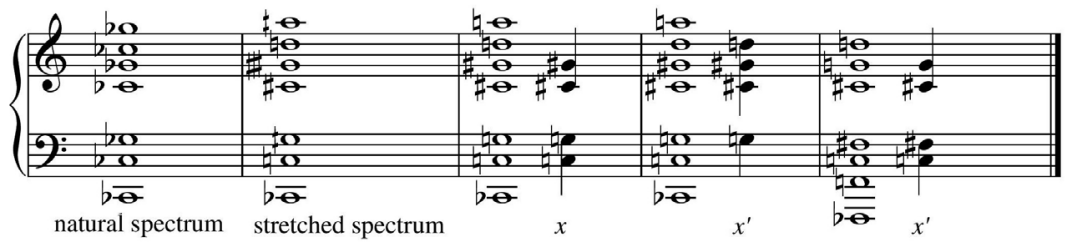

Fig. 2: Partials 1-4, 6, 8, and 12 in natural and compressed spectra; chords-z and $z^{\prime}$

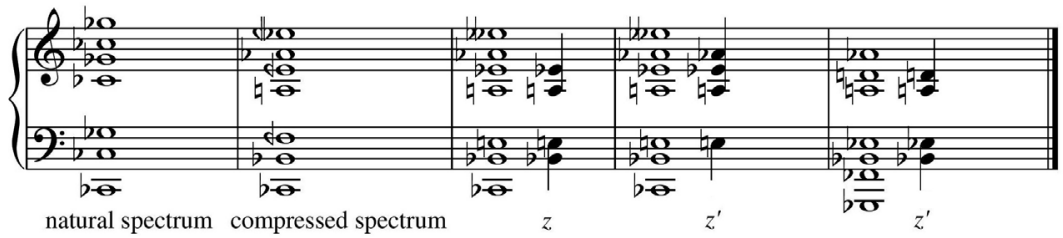

Fig. 3: Partials 1-4, 6, 8, and 12 in natural spectrum; lowered partials 3, 6, and 12; chord-y

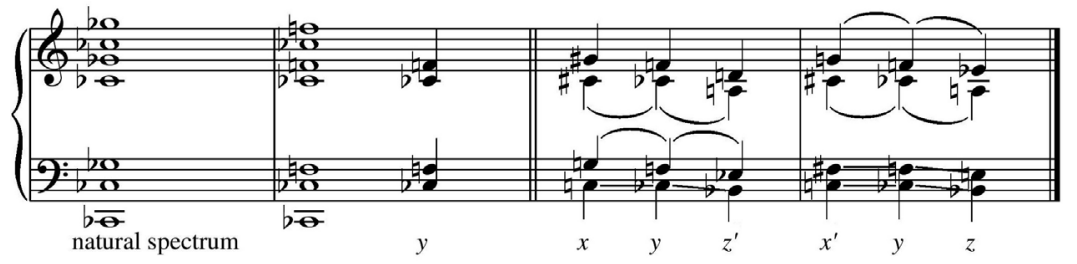

During subsection 2, the piano presents two transformations: one takes place in the low register, gradually moving from chord- $x$ to chord- $y$, while in the other, the high register is used to move from chord- $y$ to chord-z' (Ex. 10). Two percussion instruments are used for accentuation: tam-tam for the chords in the lower register, cymbals for the chords in the upper register. Both instruments produce inharmonic, bell-like spectra, making it more difficult to perceive the transformations.

28 Robert Hasegawa, "Clashing Harmonic Systems in Haas's Blumenstück and in vain," Music Theory Spectrum 37, No. 2 (2015): 210, 218. For a general account of the significance of Wyschnegradsky chords in Haas's music, see Lisa Farthofer, Georg Friedrich Haas: "Im Klange denken" (Saarbrücken: Pfau, 2007), 37-41. These authors do not distinguish between the different types of Wyschnegradsky chords, thereby placing limits on the descriptions of the processes at play in Haas's work. 
Ex. 10: Chord- $x$ to $y$ and chord- $y$ to $z^{\prime}$ transformations, mm. 25-30

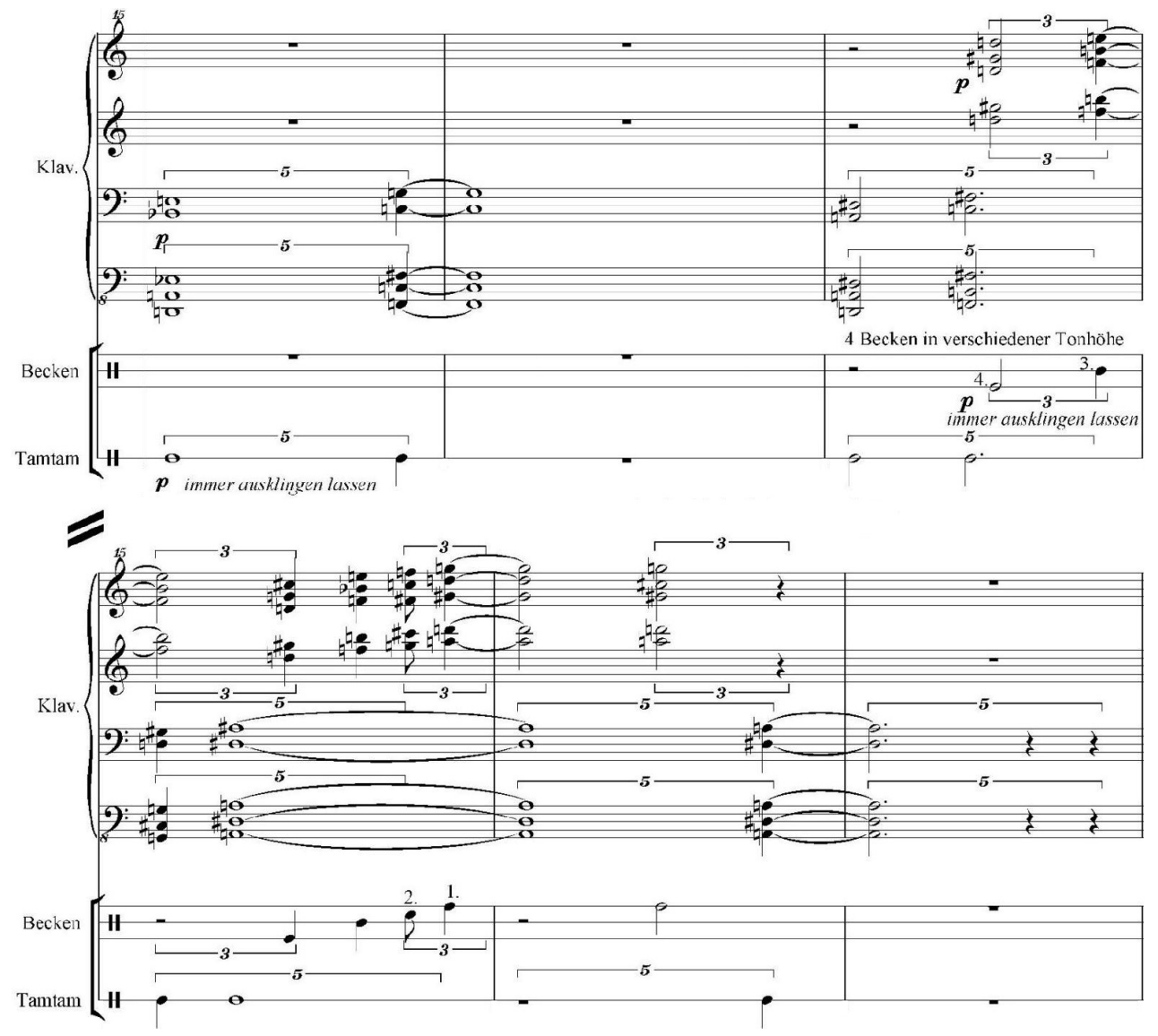

The clarinet presents a rhythmically altered version of the soprano part of Agnus Dei mm. 4-5; Ex. 11 shows the original and the altered line. The notes of the clarinet line are the roots of various transpositions of chord- $z$ (Ex. 12). The process used here is not a shift between different chord-types, but rather a spectral technique (the use of chords based on a compressed spectrum) adorning a melodic line taken from the original Agnus Dei.

Ex. 11: Agnus Dei, mm. 4-5; Tria ex Uno III mm. 59-60

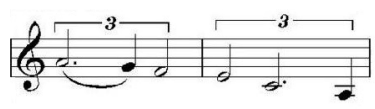

KI.(B)

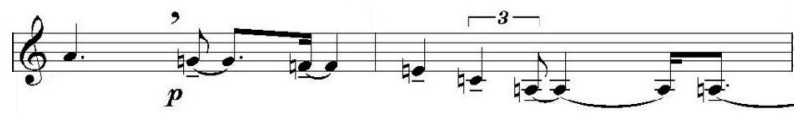


Ex. 12: Agnus Dei melodic line as roots of chord-z, Tria ex Uno III, mm 59-60

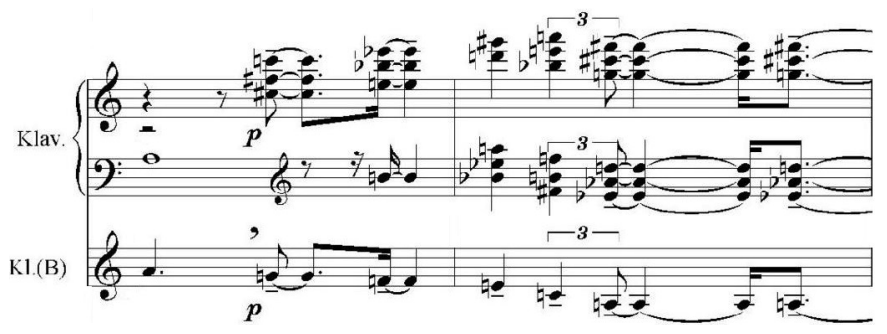

\section{Section B}

The second formal section reworks material borrowed from Agnus Dei mm. 1-2. Each portion in section $\mathrm{B}$ makes use of two processes: the first is the synthesis of a harmonic spectrum, while the second builds a Wyschnegradsky chord and/or transforms one type of Wyschnegradsky chord to another. The two processes in section B of Tria ex Uno III highlight the two contrasting tuning systems: the additive synthesis process produces sonorities in just intonation, against which Haas pits the equal temperament of the chordal process.

The first subsection in section B (mm. 77-156) is an extended development and transdialection of Agnus Dei m. 1. Throughout this subsection, spectra with D-fundamentals are used, referring to the D-harmonic spectrum used in the opening of the Agnus Dei. An F-spectrum is added in the final subsection, as in subsection 2. The synthesized emergence of spectra takes place slowly, with partials added one by one by the winds, percussion, and strings. In addition to the synthesis of harmonic spectra, the required instrumental techniques also emphasize the overtone series.

Spanning section $\mathrm{B}$, a process governs the type of spectrum produced by the continuous triplet figure played by various instruments in the ensemble. The inharmonic spectrum of a cymbal is heard first, followed by the strings playing at the bridge, producing partials close to a D-harmonic spectrum, but with added noise elements. The marimba then plays the figure, the closest semblance to the D-harmonic spectrum. The process turns back, presenting the strings again with the same performance instructions; followed by a cymbal. This process thus shades the D-spectrum from Agnus Dei m. 1 by shifting the triplet motive from inharmonicity to harmonicity, and back to inharmonicity. The move away from harmonicity is continued, shifting from the spectrum created by a single cymbal to the combination of the four different spectra produced by four cymbals; the process finds the lowest point of harmonicity in the bell-like spectrum of the tam-tam.

Near the end of the subsection (mm. 118-131), the additive synthesis and chordal processes are merged into a single process, thereby closing the gap between just intonation and equal temperament. After chord- $x$ has been built by the piano, the notes are passed to the other instruments in the ensemble. Instead of transforming one chord type to another, the process in this subsection transforms chord- $x$ to a $\mathrm{D}(1: 3: 5: 7: 11)$ spectrum 
by gradually changing the chordal notes to partials, as if by another mode of additive synthesis (Ex. 13). By combining the chordal and synthesis processes, Haas blurs the line between harmony and timbre. ${ }^{29}$

Ex. 13: Spectral and chordal processes combined, mm. 123-131

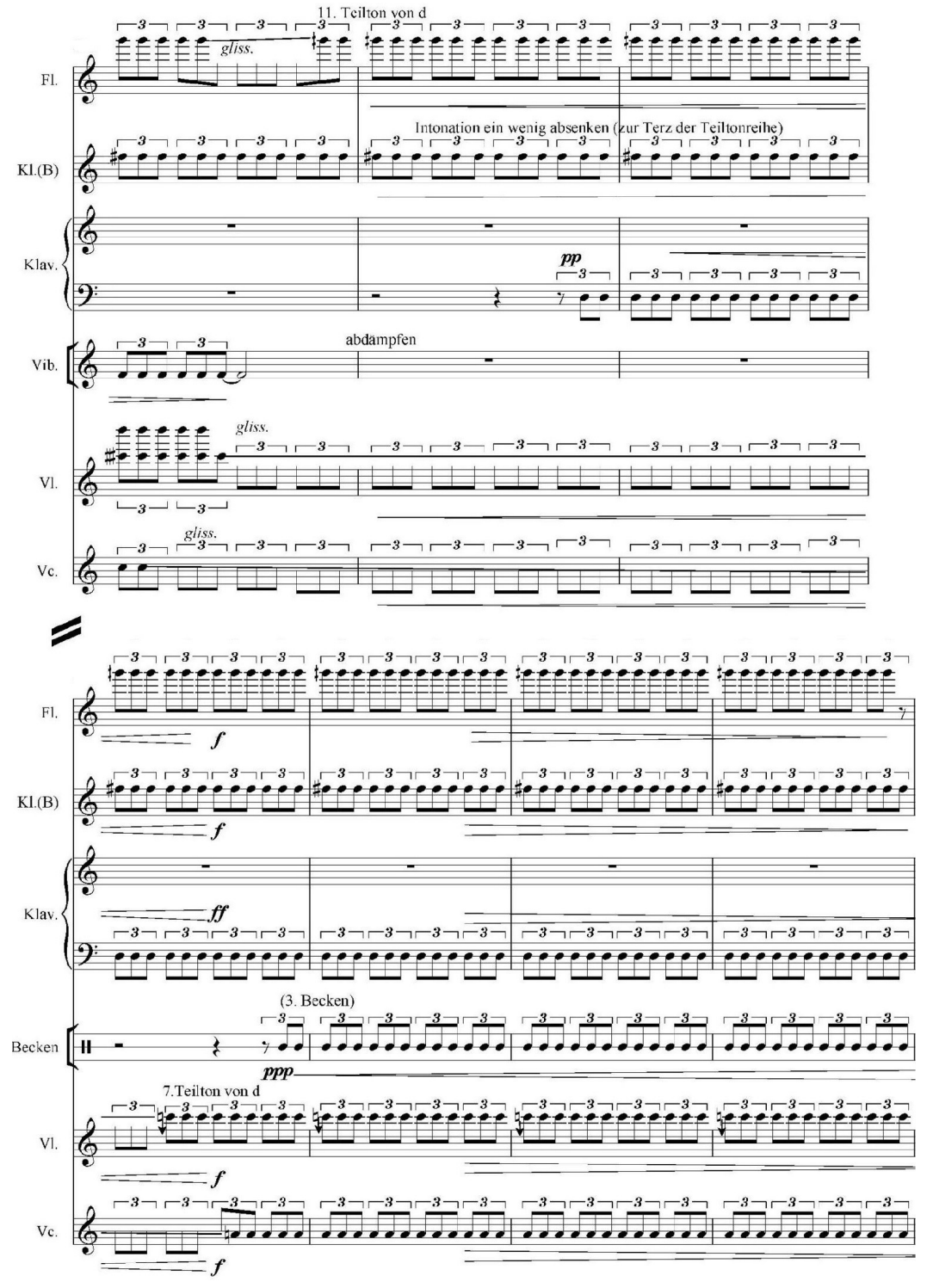

29 Rose, "Introduction to the Pitch Organization," 36. Pressnitzer \& McAdams, "Acoustics, Psychoacoustics," 39. 
Both the chordal and spectral processes change in the final subsection (mm. 157-180). Chord- $x$ ' is not transformed into another chord; instead, it is gradually transposed downward so that the upper note comes to rest on an F (which is the second pitch of the Agnus Dei melody). Instead of synthesizing a single spectrum, Haas presents two spectra simultaneously; they compete against each other. These changes in process refer to the D-F processes heard in subsection 2, which borrowed material from Agnus Dei m. 2 (cf. Ex. 6 and 7).

In concluding Tria ex Uno III with a D-F process, Haas refers to the final moments of Tria ex Uno $I$ and $I I$, in which the mensural canon comes to rest on a D-F dyad. Throughout Tria ex Uno III, the endings of melodic phrases from the Agnus Dei are used at closing sections: the $\mathrm{C}-\mathrm{G}$ end of the first phrase has been included in the fermatas near the end of section A ( $\mathrm{mm} .71-72)$; the B-natural from the end of the second phrase, completing the gamut in the Agnus Dei, is highlighted by the only use of the antique cymbal at the close of section A (mm. 74-75); and the D-F close of the third phrase has been subjected to spectral techniques to conclude Tria ex Uno III.

This study set out to determine the spectral methods Haas employs in the treatment of Josquin's Agnus Dei from Missa “L'homme armé” Super Voces Musicales. Haas's emphasis on timbre is clear in the reorchestration of the mensural canon in Tria ex Uno II. Additive synthesis has been used to create hybrid sonorities and to blur the line between timbre and harmony. The structure of Tria ex Uno III is nonlinear, and Haas makes use of various temporal adaptations. Throughout Tria ex Uno III, harmonic spectra are used at points of stability. The spectra are implemented through additive synthesis and the exploitation of various instruments' ability to produce overtones. The natural harmonic spectrum is altered to form two inharmonic spectra, stretched and compressed by one semitone per octave, respectively. These spectra provide the pitch material for the piano's Wyschnegradsky chords: stretched for chord-x; compressed for chord-z. D-F polyspectrality is used in two subsections, referring to areas in the Agnus Dei with prominent D-F dyads, using these notes as fundamentals of spectra. Harmonicity and inharmonicity are used to govern tension and release in a manner similar to that of consonance and dissonance in the Renaissance.

Various processes create structure in Tria ex Uno III. The formal organization in section $\mathrm{A}$ is based on processes of restoration and distortion, while in section $\mathrm{B}$, it is based on the synthesis of harmonic spectra and chordal transformation processes. Processes take place on a small scale within subsections (e.g., the synthesis and chordal processes in the subsections of Section B); on a medium scale within sections (e.g., the inharmonic - harmonic - inharmonic process of the triplet figure throughout section B); and on a large scale between movements (e.g., the gradual changes of the canon between Tria ex Uno $I$ and $I I$, and $I I I)$. 
My discussion of the spectral techniques used to transform the Agnus Dei has been framed by Burkholder's three types of questions to be asked of any work that employs musical borrowing. My primary aim has been to address the analytical questions; I have also placed the work in its historical context by noting the overall frequency of musical borrowing in the twentieth century as a result of an expanded stylistic distance, the less frequent phenomenon of musical "double borrowing," and the recurrence of musical borrowing in Haas's output.

Some possible answers in the interpretive realm arise from addressing the analytical and historical questions. Haas takes distinct features of the Agnus Dei and presents them in his own spectral dialect. The opening sonority of the Agnus Dei, D(2:3:4), implies the first partials of a D harmonic spectrum, which Haas extends by adding higher partials and contrasting this sonority with a different harmonic spectrum. He also exploits the premise of a mensural canon, a melody unfolding in different prolations, by reworking the original material through temporal stretching and compressing. By selecting a work from the early Renaissance, Haas creates an extreme historical distance between his music and its source material, thereby foregrounding his own compositional dialect.

Unfortunately, open sonorities, mensural canons, and historical distance are not by any means exclusive to Josquin's Agnus Dei. Neither the analytical discussion nor the historical context sheds definitive light on the interpretive realm, but it is my hope that this lacuna is not seen as a disappointing end of the road, but rather as a space that can yet be filled through engagement with other fields and methodologies.

\title{
Processes of spectralization: From Josquin's Missa "L’homme armé" Super Voces Musicales to Haas's Tria ex Uno
}

\begin{abstract}
This article sheds new light on Georg Friedrich Haas's borrowing methods through an analysis of Tria ex Uno, which paraphrases a piece published half a millennium earlier: the Agnus Dei II from Josquin des Prez's Missa "L'homme armé" super voces musicales, which employs borrowing techniques itself. I demonstrate the transformation from the Agnus Dei II to Tria ex Uno by revealing Haas's specific spectral paradigms and techniques within a framework of Peter Burkholder's and Richard Beaudoin's work on musical borrowing. My study thus provides a means to understand the spectral treatment of existing music within the discourse on musical borrowing.
\end{abstract}




\title{
Procesy spektralizace: od Josquinovy skladby Missa „L'homme armé” Super Voces Musicales k dílu Tria ex uno Georga Friedricha Haase
}

\begin{abstract}
Abstrakt
Studie se zabývá metodou hudebních citátů Georga Friedricha Haase prostřednictvím analýzy skladby Tria ex uno; díla, které parafrázuje hudební kus vzniklý o pět set let dřive Agnus Dei II ze skladby Missa "L'homme armé" super voces musicales od Josquina des Prez, který sám o sobě vychází z principů přebírání cizího hudebního materiálu. Transformace Agnus Dei II v Tria ex uno je vysvětlena pomocí definice Haasova specifického spektrálního paradigmatu a technik v teoretickém kontextu hudebního citování Petera Burkholdera a Richarda Beaudoina. Studie nabízí nástroje k pochopení spektrálního zpracování existující hudby $\mathrm{v}$ rámci diskurzu hudebního citování.
\end{abstract}

\section{Keywords}

Georg Friedrich Haas; intertextuality; Josquin des Prez; musical borrowing; spectralism.

\section{Klíčová slova}

Georg Friedrich Haas; intertextualita; Josquin des Prez; hudební citát; spektralismus. 